University of Nebraska - Lincoln

DigitalCommons@University of Nebraska - Lincoln

Publications from USDA-ARS / UNL Faculty

U.S. Department of Agriculture: Agricultural

Research Service, Lincoln, Nebraska

2001

\title{
Assessing Site Vulnerability to Phosphorus Loss in an Agricultural Watershed
}

Andrew N. Sharpley

USDA-ARS

Richard W. McDowell

USDA-ARS

Jennifer L. Weld

USDA-ARS

Peter J. A. Kleinman

USDA-ARS

Follow this and additional works at: https://digitalcommons.unl.edu/usdaarsfacpub

Part of the Agricultural Science Commons

Sharpley, Andrew N.; McDowell, Richard W.; Weld, Jennifer L.; and Kleinman, Peter J. A., "Assessing Site Vulnerability to Phosphorus Loss in an Agricultural Watershed" (2001). Publications from USDA-ARS / UNL Faculty. 269.

https://digitalcommons.unl.edu/usdaarsfacpub/269

This Article is brought to you for free and open access by the U.S. Department of Agriculture: Agricultural Research Service, Lincoln, Nebraska at DigitalCommons@University of Nebraska - Lincoln. It has been accepted for inclusion in Publications from USDA-ARS / UNL Faculty by an authorized administrator of DigitalCommons@University of Nebraska - Lincoln. 


\title{
Estrogenic Activity in the Environment: Municipal Wastewater Effluent, River, Ponds, and Wetlands
}

\author{
Nancy W. Shappell*
}

\begin{abstract}
Estrogenic activity of regional water samples was evaluated. Samples obtained from wetlands and ponds involved in various agricultural land uses, from three river sites over four seasons, and from municipal wastewater effluent held in storage lagoons were evaluated. The estrogen-responsive cell line MCF-7 BOS was used in the E-screen assay to determine 17 $\beta$-estradiol equivalents $\left(E_{2} E_{q}\right)$ of water samples extracted by solid-phase extraction. Estrogenic activity in surrounding wetlands and ponds from different land uses was not different, with $10^{-12} M E_{2}$ Eq (0.3 ppt). Estrogenic activity of Red River samples was within the same range as wetland-pond samples. The highest activity was found downstream from municipal wastewater treatment effluent discharge sites, in winter when river flow was lowest (approximately $\left.6 \times 10^{-13} M E_{2} \mathrm{Eq}\right)$. Results showed that 7 of 20 wetland-pond samples and 5 of 12 river samples were below the limits of quantitation (approximately $3 \times 10^{-14} M \mathrm{E}_{2} \mathbf{E q}$ ). Toxicity was found in fall and summer river samples upstream from municipal wastewater release sites. The timing of toxicity did not coincide to the presence of elevated fecal coliforms. Estrogenic activity in wastewater effluent from lagoons decreased over time (approximately 25 to $5 \times 10^{-13} M \mathrm{E}_{2} \mathbf{E q}$ ) with an apparent half-life of $8 \mathrm{~d}$ for one lagoon. The median concentration of detectable estrogenic activity in regional water samples was approximately 50 -fold less than the median $17 \beta$-estradiol concentration of estradiol detected in some U.S. streams in previous studies.
\end{abstract}

$\mathrm{W}$ ITH ADVANCES in technology and instrumentation, scientists are now able to detect chemical residues in parts per trillion (ppt). While Kolpin et al. (2002) reported that 82 organic wastewater contaminants were present in streams across the United States, the biological consequences of many of these chemicals at the concentrations detected are unknown. Also unknown are the biological effects of mixtures of these chemicals on organisms. Endocrine disruption as a result of anthropogenic activity has become a relatively recent concern, initiated by the work of Guillette, Jr. et al. (1994) reporting that alligators in contaminated Florida lakes had abnormal gonad development and sex hormone concentrations. Other studies (Harries et al., 1996; Allen et al., 1999) have found contaminated waters to be associated with vitellogenin production (a protein normally only produced in the liver of female fish in response to estradiol) and intersex gonads (oocytes present in testes) in male fish. Organismal research conducted at environmen-

USDA-ARS, Animal Metabolism Unit, Biosciences Research Laboratory, 1605 Albrecht Boulevard, Fargo, ND 58105. Mention of trade names or commercial products in this article is solely for the purpose of providing specific information and does not imply recommendation or endorsement by the USDA. Received 6 Dec. 2004. *Corresponding author (shappeln@fargo.ars.usda.gov).

Published in J. Environ. Qual. 35:122-132 (2006).

Technical Reports: Surface Water Quality

doi:10.2134/jeq2004.0464 tal sites of concern requires extended study periods and is expensive, labor intensive, and subject to vandalism.

Several in vitro assay systems have been developed to assess estrogenic activity. One type of assay is receptor based. These assays indicate receptor binding or estradiol displacement (which may or may not result in downstream activation or inhibition). Another type of assay uses cells (either mammalian or yeast) transfected with DNA for estradiol receptors. The feedback mechanisms that would normally be present in cells responsive to estradiol would not be found in yeast. Transfected mammalian cells would not have receptor numbers equivalent to unaltered cells. Therefore these assay types do not reflect true cellular potential. Some of the limitations associated with risk assessment of estrogenic compounds using these types of assays were addressed by Safe et al. (2002).

The in vitro E-screen assay developed by Soto et al. (1995) allows for determination of estrogenic activity of samples using a human mammary carcinoma cell line that is dependent on estrogen receptor activity for proliferation. These cells have not been genetically manipulated by scientists, and therefore reflect their natural physiological state (first conceding that they are derived from a carcinoma and not "normal" tissue). The assumption is that unaltered cells in whole organisms, with estrogen receptors, have the cellular potential to react in a similar manner. The E-screen assesses a biological endpoint (cell proliferation), so not only does a substance need to bind to the receptor, it must be capable of eliciting a coordinated sequence of events stimulated by estradiol binding. Estrogen-independent proliferation can be established by co-incubation of sample with an estrogen receptor antagonist. Unlike enzyme-linked immunosorbent assays (ELISAs), which are designed for their chemical specificity and lack of cross-reactivity, the E-screen can detect activity in environmental samples without any information as to the chemical structure of compounds present. Currently environmental samples are being screened using an ELISA for estradiol, which would not detect many compounds in environmental samples that have been shown to have estrogenic activity (e.g., Peterson et al., 2000). Before agricultural and industrial practices can be evaluated for their effects on estrogenicity of environmental waters, an idea of "indigenous" levels of activity (from natural as well as anthropogenic activity) in our water supplies must be established. Therefore this study evaluated the estrogenic activity of water samples from wetlands and ponds from

Abbreviations: CRP, Conservation Reserve Program; ELISA, enzyme-linked immunosorbent assay; $\mathrm{E}_{2}, 17 \beta$-estradiol; $\mathrm{E}_{2}$ Eq, 17 $\beta$-estradiol equivalents; LC-MS/MS, liquid chromatography-tandem mass spectrometry; MWWTP, municipal wastewater treatment plant; RR, Red River; TSS, total suspended solids. 
A
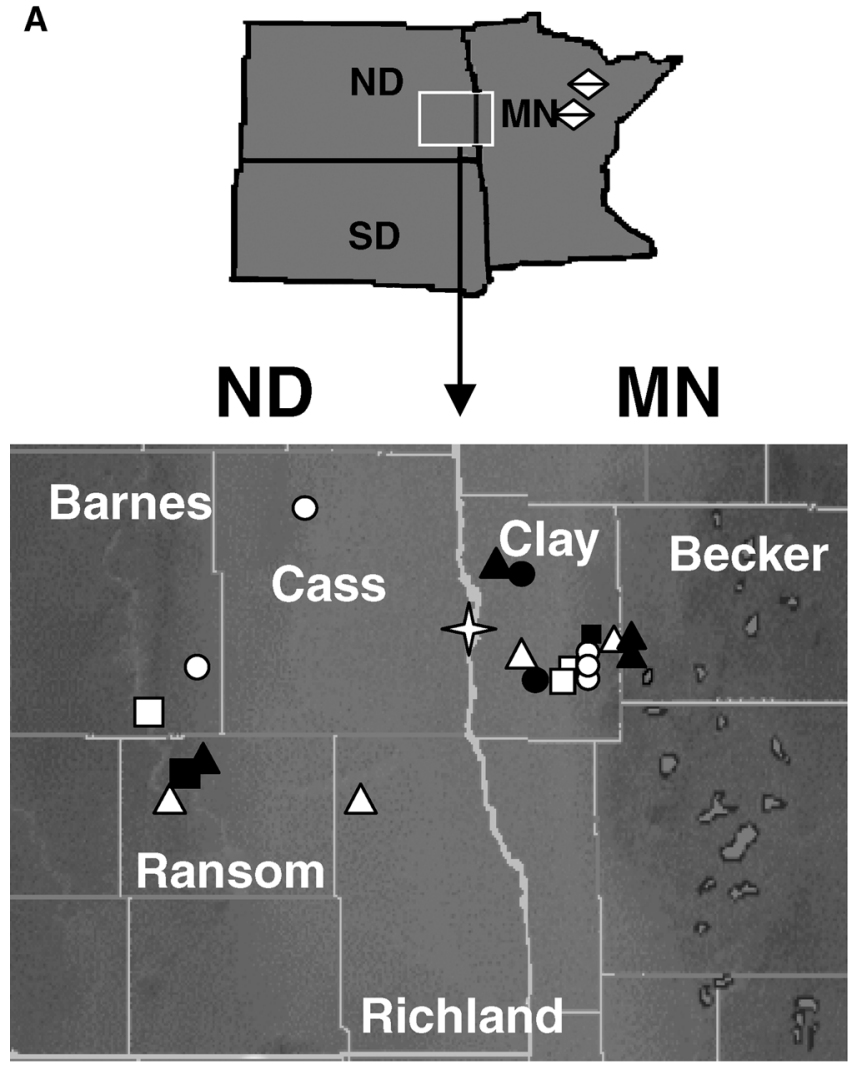

$\neg$ Fargo/Moorhead

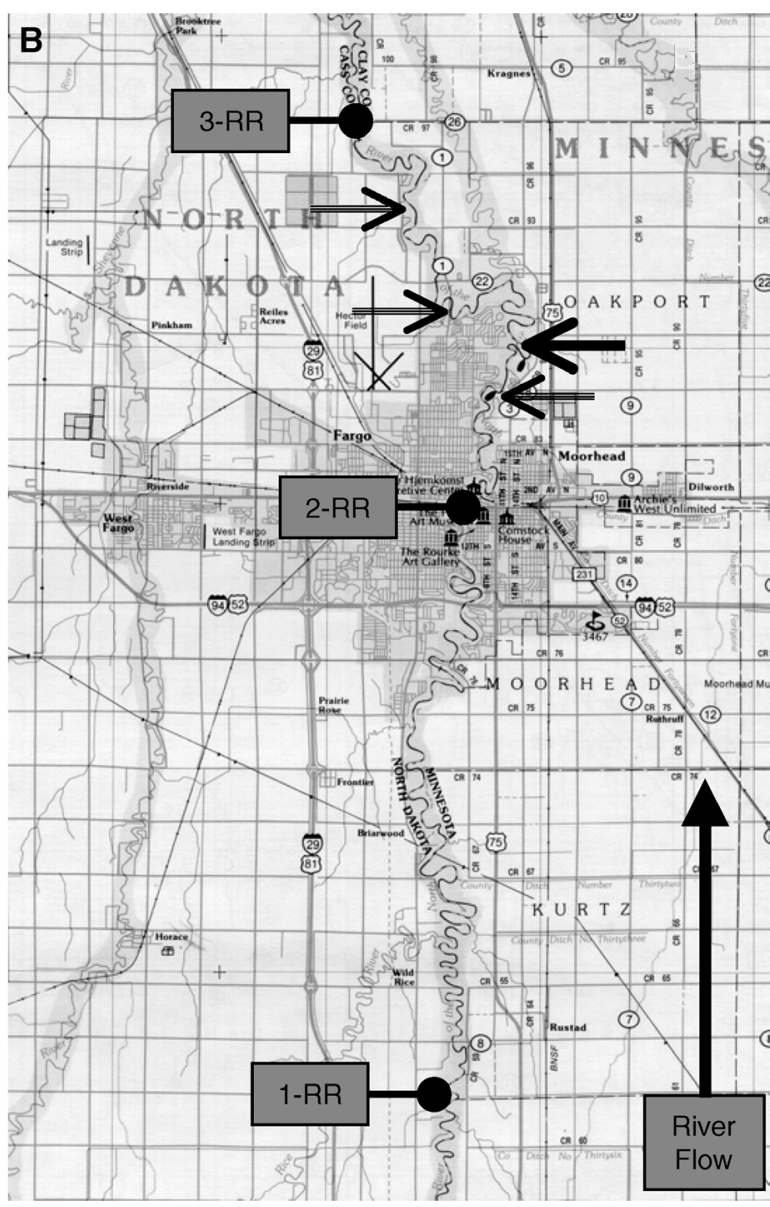

Fig. 1. (A) Wetland and pond site map of North Dakota and Minnesota with surrounding land use: $\bigcirc$, wheat-soybeans; $\bullet$, wheat-sugarbeets; $\triangle$, livestock; $\square$, alfalfa-soybeans; $\square$, alfalfa; $\Delta$, Conservation Reserve Program (CRP)-grassland; and $\diamond$, previously high frequencies of malformations and Ribeiroia infection in Rana pipiens. (B) Red River (RR) sampling sites in the Fargo-Moorhead area. The river flows from south to north. The location of municipal wastewater discharge sites is indicated by arrows $(\rightarrow)$, while the agricultural wastewater release site is indicated by a larger arrow $(\rightarrow)$. Sampling sites are indicated by 1-RR, 2-RR, and 3-RR.

locations uninvolved with agriculture and involved in various agricultural land uses; from three river sites over four seasons; and from municipal wastewater effluent held in storage lagoons.

\section{MATERIALS AND METHODS}

\section{Site Selection and Sample Collection}

\section{Wetlands and Ponds}

Water samples were collected from study sites investigating the effect of land use on northern leopard frog (Rana pipiens) health and parasite burden. Twenty sites, consisting of semipermanent and permanent ponds or wetlands, were chosen within an approximate 160-km radius of Fargo, ND (Fig. 1A). Two additional outlier sites in Minnesota were included due to histories of high malformation rates and Ribeiroia infection (Vandenlangenberg et al., 2003). The habitat surrounding the agriculturally active sites consisted of a landscape with crops [soybean, Glycine max (L.) Merr.; wheat, Triticum aestivum L.; sugarbeet, Beta vulgaris L.; and/or alfalfa, Medicago sativa L.] or livestock (cattle and/or horses). The sites categorized as agriculturally inactive were comprised of either grassland or Conservation Reserve Program land (CRP, referring to fields that had not been used for crop production for at least 3 to $5 \mathrm{yr}$ ). One-liter water samples were collected in late spring, early summer 2001, where tadpoles were present, in EPA Level 1 precleaned high density polyethylene bottles (Eagle Picher; VWR Scientific, South Plainfield, NJ) and stored at $-20^{\circ} \mathrm{C}$.

\section{River Sites}

Water samples from a river upstream from a metropolitan area, midtown, and post-wastewater effluent release were collected by the Energy \& Environmental Research Center on the Red River (RR): 1-RR upstream, Cass Co. 16; 2-RR midtown, Main Ave., Fargo, ND; and 3-RR, post-wastewater effluent discharge, Cass Co. 22 (Fig. 1B). Distance between sites was $36.4 \mathrm{~km}$ (1-RR to 2-RR) and $29.4 \mathrm{~km}$ (2-RR to $3-\mathrm{RR})$. Water was collected using a Wildco $4.2 \mathrm{~L}$ vertical beta bottle water column sampler (Wildlife Supply Co., Buffalo, NY) from a depth of $60 \%$ from the top of the water column on 10 Oct. 2001, 21 Jan. 2002, 23 Apr. 2002, and 23 July 2002. One-liter samples were transferred to high density polyethylene bottles described above. Holes were bored in ice to obtain samples in January. River flow data (corrected for ice cover) were provided by the USGS (2002). Fecal coliform count (Method 9222) and total suspended solids (TSS) (Method 2540D; American Public Health Association, 1998) data were obtained from Energy \& Environmental Research Center and municipalities (Method 2540D). To estimate TSS released per month, the average recorded TSS concentration 
was multiplied by the total recorded volume released and summed for the month.

\section{Municipal Wastewater Lagoons}

A regional wastewater treatment plant provided access to waste stabilization ponds (holding lagoons) approximately 0.4 ha (1 acre) each in size. In two lagoons, no wastewater effluent was added for approximately 8 mo (fall 2001 through spring 2002). Three other lagoons were emptied and refilled with fresh wastewater effluent to the depth of the two undisturbed lagoons (approximately $2 \mathrm{~m}$, over $35 \mathrm{~d}$ ). Samples were collected on three sides of each lagoon and a composite sample was made at the completion of filling (24 June 2002, designated Day 0) and on Days 4, 8, 16, 28, 42, 84, and 295. Bottles used were as described above.

\section{Sample Extraction}

All glassware used for sample preparation was washed with Liqui-Nox (MG Scientific, Pleasant Prairie, WI), rinsed with nanopure water, dried and rinsed with acetone, methanol, acetonitrile, ethyl acetate, and methylene chloride, and then baked at $450^{\circ} \mathrm{C}$ for $4 \mathrm{~h}$. Solvents were high performance liquid chromatography (HPLC) or gas chromatography (GC) grade, $\geq 99.8 \%$ pure. Methanol and methylene chloride were obtained from Fisher Scientific (Hampton, NH), acetone from Burdick/Jackson (Muskegon, MI), ethyl acetate and acetonitrile from EMD Chemicals (Gibbstown, NJ), and tert-butyl methyl ether from Aldrich (Milwaukee, WI). Water samples were brought to room temperature and shaken, and large particulates were allowed to settle for $1 \mathrm{~h}$ before the transfer of $250 \mathrm{~mL}$ to a glass separatory funnel. Samples were not filtered, so fine particulates in the water (to which fish and other aquatic organisms would be exposed) were included in the extraction. The aim of water extraction was to maximize retention of all organic compounds, not just those with chemical properties resembling estrogens. Therefore, an Oasis Hydrophilic-Lipophilic Balance Sorbent glass solid-phase exchange cartridge (HLB, 200-mg packing; Waters, Milford, MA) was chosen and a solvent series used to elute hydrophilic and hydrophobic compounds. Cartridges were activated using two 3-mL rinses of the following solvent series: acetone, methanol, acetonitrile, ethyl acetate, methylene chloride, tert-butyl methyl ether, and nanopure water. Samples were loaded onto the cartridge and vacuum was applied $(26-56 \mathrm{~cm} \mathrm{Hg})$. Retained material was eluted using $3 \mathrm{~mL}$ of each solvent listed above, and taken to dryness under $\mathrm{N}_{2}$ at $37^{\circ} \mathrm{C}$. Extraction efficiencies were assessed using ${ }^{14} \mathrm{C}$-radiolabeled $17 \beta$-estradiol $\left(\mathrm{E}_{2}\right)$ and testosterone (specific activity approximately $50 \mathrm{mCi} \mathrm{mmol}^{-1}$ each, tested at approximately $1.5 \times 10^{-8} \mathrm{M}$; American Radiolabeled Chemical, St. Louis, MO). Sample extracts were redissolved first in $80 \mu \mathrm{L}$ of nanopure water (to aid in resuspension) followed by the addition of $3 \mathrm{~mL}$ ethanol (Warner Graham Co., Cockeysville, MD), transferred to a sterile vial, and dried again using conditions described above. Final sample resuspension volume was typically $80 \mu \mathrm{L}$ (nanopure water) from which a 1:100 dilution was made in white media (as defined below) for testing on cells.

\section{Cell Culture}

Estrogen-sensitive MCF-7 BOS cells derived from a human mammary carcinoma (from the laboratory of Dr. Ana Soto and Dr. Carlos Sonnenschein, Tufts University School of Medicine, Boston, MA) were passed weekly at $4 \times 10^{4}$ cells in a $25-\mathrm{cm}^{2}$ flask. Chemicals were obtained from Sigma Chemical (St. Louis, MO), except as noted. Cells were maintained at $37^{\circ} \mathrm{C}, 6 \% \mathrm{CO}_{2}$ to $94 \%$ air under saturating humidity, in
Dulbecco's modified Eagle's medium (DMEM; MP Biomedical, Irvine, $\mathrm{CA}$ ) with $2.25 \mathrm{~g} \mathrm{~L}^{-1}$ sodium bicarbonate, $\mathrm{pH} 7.1$, and $5 \%$ heat-inactivated $\left(\mathrm{HI} ; 57^{\circ} \mathrm{C}, 30 \mathrm{~min}\right)$ defined fetal bovine serum (HI-FBS; HyClone, Logan, UT). Cells were harvested with $0.05 \%$ trypsin in $0.1 \%$ glucose, $0.5 \mathrm{~m} M$ EDTA phosphate-buffered saline and disrupted with an 18 gauge needle (five passes) before counting.

\section{Steroid Stripping of Serum}

Serum was stripped of steroids using a technique slightly modified from Wiese et al. (1992). Dextran T-70 (Amersham Pharmacia Biotech, Piscataway, NJ) was combined with washed activated charcoal and HI-FBS in a ratio of 0.5:5.0:94.5 in glass centrifuge tubes, shaken, and then incubated under continuous rotation for $1 \mathrm{~h}\left(6 \mathrm{RPM}, 37^{\circ} \mathrm{C}\right)$. Stripping was performed at $37^{\circ} \mathrm{C}$, the temperature at which cells are treated, to ensure release of steroids from all serum components. Tubes were centrifuged at $2000 \times g$ for $20 \mathrm{~min}$. Serum was subsequently filtered through 0.8 - and $0.45-\mu \mathrm{m}$ filters, sterilefiltered using a $0.2-\mu \mathrm{m}$ filter, and stored at $-60^{\circ} \mathrm{C}$. Pre- and post-stripping serum estradiol and testosterone concentrations were determined using ELISAs according to kit directions (Cayman Chemical, Ann Arbor, MI).

\section{E-Screen Assay}

Water samples were tested using the proliferation assay, or E-screen assay, following procedures essentially the same as Soto et al. (1995). Cells were plated in 96 well plates (Linbro; MP Biomedical) at $5 \times 10^{3}$ cells well ${ }^{-1}$ in $200 \mu \mathrm{L}$ DMEM with $5 \%$ HI-FBS. One day later, media was removed and replaced with sample extract suspended in "white media"-DMEM without phenol red (Irvine Scientific) supplemented with 10\% CD-FBS (charcoal-dextran stripped), $1 \mathrm{~m} M$ sodium pyruvate and $4 \mathrm{~m} M$ L-glutamine (Invitrogen, Carlsbad, CA), $15 \mathrm{~m} M$ HEPES, and $100 \mathrm{U} \mathrm{mL}^{-1}$ penicillin. Phenol red was omitted due to its estrogenic properties. Border wells were filled with media without cells. A standard dose response curve was run using $E_{2}$ with six wells per concentration (Fig. 2). All plates contained one column in which cells received CD-FBS media only. On plates without standards, one column of cells received $\mathrm{E}_{2}\left(1 \times 10^{-11} M\right)$. Recoveries of E-screen $17 \beta$-estradiol equivalents $\left(\mathrm{E}_{2} \mathrm{Eq}\right)$ were determined by liquid chromatographytandem mass spectrometry (LC-MS/MS) analysis of estradiol standards in matrix samples or nanopure water (approximately $50 \mathrm{~mL}$ each of 10,50 , or $100 \mathrm{pg} \mathrm{mL}^{-1}$ and containing $100 \mathrm{pg}$ $\mathrm{mL}^{-1}$ deuterated estradiol).

Sample extracts were tested on cells from approximately 0.1 to 30 times the original concentration. In one well, sample was co-incubated with $\mathrm{E}_{2}$ as a screen for toxicity. Proliferation should be a sum of sample response by itself plus $E_{2}$ alone (within the linear range). Toxicity was indicated when proliferation was less than the sum of the two, and reported as a percentage of expected $\mathrm{E}_{2}$ response $(100 \%=$ no toxicity $)$. The $\mathrm{E}_{2}-$ receptor dependence of the proliferative response was evaluated by co-incubation with $5 \times 10^{-9} M$ of $\mathrm{E}_{2}$-receptor antagonist ICI 182,780 (Tocris, Ellisville, MO; Wakeling et al., 1991; Rasmussen and Nielsen, 2002). Cells were then incubated for $5 \mathrm{~d}$, after which they were fixed with trichloroacetic acid $(10 \%$ on ice, $30 \mathrm{~min})$. Cell protein was stained with sulforhodamine B (SRB) essentially as described by Skehan et al. (1990). Fixation time was extended to $1 \mathrm{~h}$ in trichloroacetic acid and staining time to $30 \mathrm{~min}$, and solubilization volume decreased to $100 \mu \mathrm{L}$ well ${ }^{-1}$. Plates were read at $\mathrm{A}_{490}$ on a plate reader (Victor 1420; Wallac, Turku, Finland) and $\mathrm{E}_{2}$ Eq extrapolated from the standard curve. 


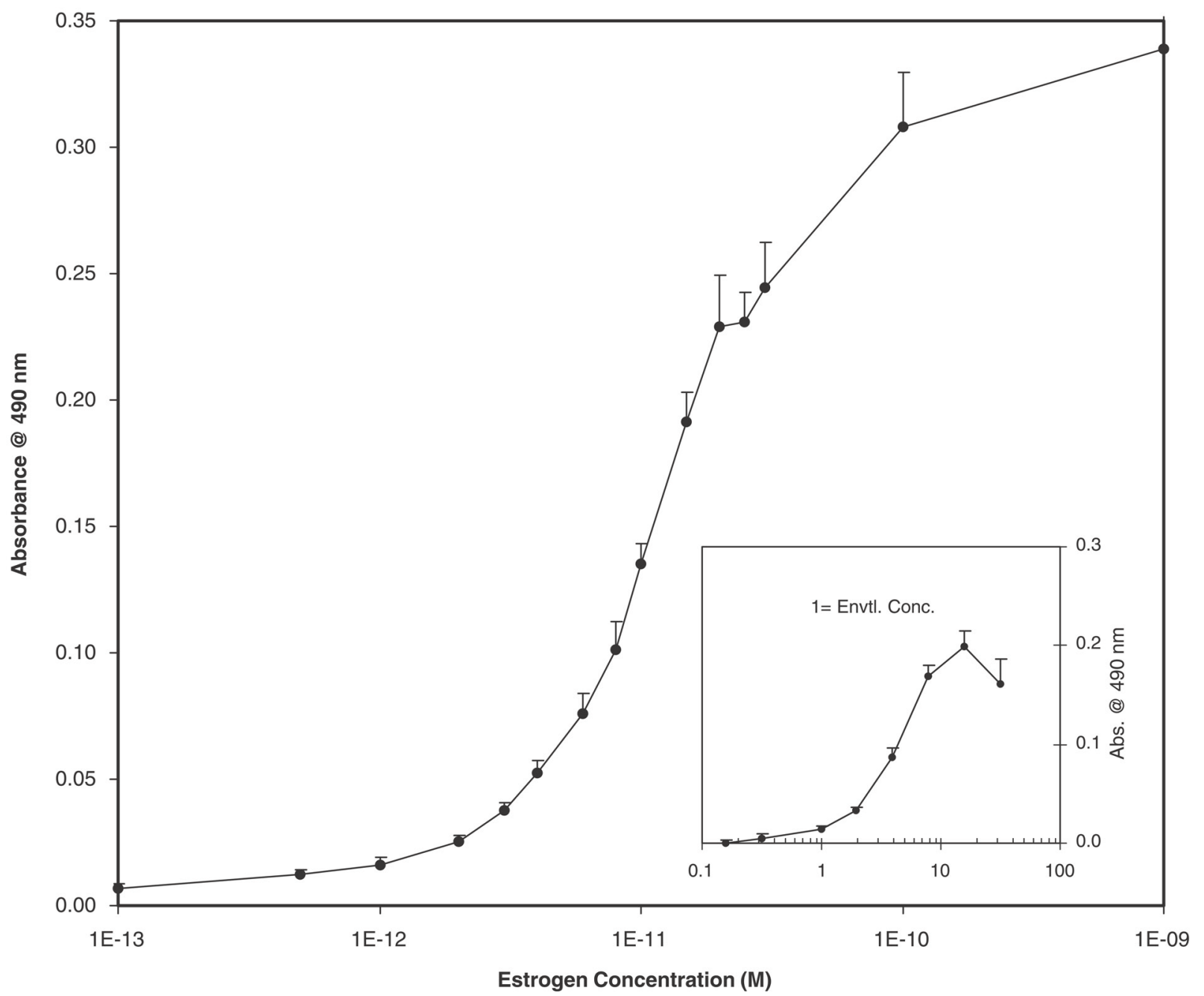

Fig. 2. Representative standard curve of $17 \beta$-estradiol (mean $\pm S D, n=6$ ). The insert shows actual data from municipal wastewater holding Lagoon 1 on Day 0 tested over several concentrations $( \pm S D, n=5)$. The $x$ axis represents sample concentration, while $1=$ environmental concentration.

\section{Statistical Analysis}

Statistical analyses were performed to assess trends of estrogenic activity and land use (frog sites) and seasonality (Red River sites). Estrogenic activity was statistically compared using a generalized linear model (PROC GLM; SAS Institute, 1999) for a completely randomized design with land use as a fixed effect and site as the experimental unit. Homogeneity of variances was substantiated using Levene's test $(P=0.620)$. Estrogenic activity of Red River samples was analyzed using Repeated Measures Analysis with site the subject and season the fixed effect (PROC MIXED; SAS Institute, 1999).

\section{RESULTS AND DISCUSSION}

\section{Method Evaluation}

Estradiol and testosterone concentrations of prestripped serum determined by ELISAs were approximately $150 \mathrm{pg}$ $\mathrm{mL}^{-1}\left(5.5 \times 10^{-10} M\right)$ and approximately $50 \mathrm{pg} \mathrm{mL}^{-1}(1.7$ $\left.\times 10^{-10} M\right)$, respectively. Post-stripping, estradiol values were below ELISA detection limits of $9 \mathrm{pg} \mathrm{mL}^{-1}(3.3 \times$ $\left.10^{-11} M\right)$ for estradiol and $1.95 \mathrm{pg} \mathrm{mL}^{-1}\left(6.8 \times 10^{-12} \mathrm{M}\right)$ for testosterone. Lack of proliferative response of cells grown in media containing $10 \%$ CD-FBS indicated un- diluted stripped serum contained less than $1 \times 10^{-11} M \mathrm{E}_{2}$ Eq. These results indicate satisfactory removal of estradiol and testosterone from serum.

Recoveries of radiolabeled testosterone and estradiol were $\geq 95 \%$ and extraction efficiencies on SPE columns averaged $95 \%$ for samples spiked in either nanopure water or wastewater effluent. Comparison of extracted estradiol standards (approximately $50 \mathrm{~mL}$ each of 10,50 , or $100 \mathrm{pg} \mathrm{mL}^{-1}$ in nanopure water containing $100 \mathrm{pg}$ $\mathrm{mL}^{-1}$ deuterated estradiol) yielded an average of $87 \%$ of predicted values. In the presence of matrix estradiol standard recoveries were similar (106\% of expected). Limit of quantitation was $1 \times 10^{-12} M \mathrm{E}_{2}$ Eq of extract as applied to cells or $3 \times 10^{-14} M$ of original sample (as concentrated 30-fold). Interassay variation of $\mathrm{E}_{2} \mathrm{Eq}$ samples was $\leq 5 \%$, and variation on separate extractions was $\leq 10 \%$. Linearity of SRB absorbance and cell number were found to be as previously reported (Korner et al., 1998) and in our lab $R^{2}=0.991$ for $1 \times 10^{3}$ to $4 \times$ $10^{4}$ cells.

One caveat of the E-screen assay when used on an environmental sample is that the reported estrogenic activity actually reflects the sum of effects of a complex 
mixture on the cells. This may include both anti-estrogenic effects and generalized toxicities. Interpretation of results requires that this caveat be kept in mind. Some extracts were found to result in a lack of cellular proliferation in the presence of added $\mathrm{E}_{2}$. Using the conditions of the E-screen assay, MCF-7 cells do not provide a very sensitive tool to assess toxicity. Therefore, an attempt to differentiate toxicity from anti-estrogenic activity was made using two other cell lines (MDA-23, ATCC \#HTB-26, derived from the same patient as MCF-7 BOS, but cited as estrogen-insensitive; and WI-38, ATCC \#CCL-75, a human lung fibroblast cell line). The proliferative responses of both lines were evaluated in the presence of estradiol over the concentrations used with the MCF-7 standard curve, testosterone from $1 \times 10^{-12}$ $M$ to $1 \times 10^{-5} M$, and ICI 182,780 (estrogen receptor antagonist) at $5 \times 10^{-9} M$. The addition of ICI 182,780, estradiol, or testosterone caused no change in proliferation for either cell line.

\section{Wetlands and Ponds}

Estrogenic activity of water samples from wetlands and ponds was not different based on land use $(P=$ 0.847 ; Fig. 3). Variability between sites within a land use was greater than the difference of the means for land use. Of the sites evaluated, 7 of $20(35 \%)$ were below the limits of quantitation $\left(<3 \times 10^{-14} M \mathrm{E}_{2} \mathrm{Eq}\right)$. The estrogenic activity values of the remaining sites all fell within approximately one order of magnitude (e.g., 1 to $10 \times$ $10^{-13} M \mathrm{E}_{2} \mathrm{Eq}$ ). While making a direct comparison of $\mathrm{E}$ screen $\mathrm{E}_{2} \mathrm{Eq}$ to LC-MS/MS results of pure compounds makes many assumptions such as lack of toxic or antiestrogenic effects, it provides a framework for comparison of concentrations obtained from chemical analysis with biological responses to complex environmental samples. In the $10 \%$ of U.S. streams tested by Kolpin et al. (2002) with detectable $\mathrm{E}_{2}$, the median concentration was approximately $3 \times 10^{-11} M$ and the maximum was $7 \times 10^{-10} M$ (limit of quantitation was $4 \times 10^{-11} M$ ).
The median detectable estrogenic activity of ponds and wetlands sampled in Minnesota and North Dakota was $5.2 \times 10^{-13} M \mathrm{E}_{2} \mathrm{Eq}$, approximately 50-fold less than the median $\mathrm{E}_{2}$ concentration reported by Kolpin et al. (2002). This group also reported that $17 \alpha$-ethinylestradiol (the estrogen used in birth control pills) was detected at approximately $16 \%$ of their sites, with a median concentration of $2.5 \times 10^{-10} \mathrm{M}$ and a maximum of $2.8 \times 10^{-9} \mathrm{M}$. The $\mathrm{E}_{2} \mathrm{Eq}$ of ethinylestradiol is 1 . Combining concentrations of ethinylestradiol and $\mathrm{E}_{2}$ concentrations from Kolpin's study, the resultant $\mathrm{E}_{2} \mathrm{Eq}$ for the median would be $2.8 \times 10^{-10} M$ and sample maximum would be $3.5 \times$ $10^{-9} M, 100$-fold the greatest concentration reported here. This is not surprising as the authors suggested that their choice of sites favored the presence of chemical contamination (due to proximity to municipal wastewater treatment plants [MWWTPs] and farms). The estrogenic activity at the two outlier sites in Minnesota with a previous history of frog malformations was also found to be low; one site categorized as CRP land use was below the limits of quantitation; the second, which could have been impacted by livestock, was $1.5 \times 10^{-13} M \mathrm{E}_{2}$ Eq. All sample-induced proliferation was determined to be estrogen-dependent as proliferation was inhibited when cells were co-incubated with extract and the estrogen receptor antagonist ICI 182,720. This was also found for river, municipal wastewater effluent, and lagoon samples.

Unexpectedly, CRP land use sites, which represented more undisturbed sites, had estrogenic values similar to those sites that were used by livestock. This may be due to the presence of more waterfowl at CRP sites. Avians have been reported to have higher levels of circulating estradiol (approximately $380 \mathrm{pg} \mathrm{mL}^{-1}$ or $1.4 \times 10^{-9} \mathrm{M}$; Cockrem and Rounce, 1994) than mammals, including humans (approximately $30-200 \mathrm{pg} \mathrm{mL}^{-1}$ or $0.1-0.7 \times$ $10^{-9} M$; Baird and Guevara, 1969; Munro et al., 1991).

While the sites in this study designated as livestock land use were impacted by livestock, they should not be construed as equivalent to sites found in a concentrated

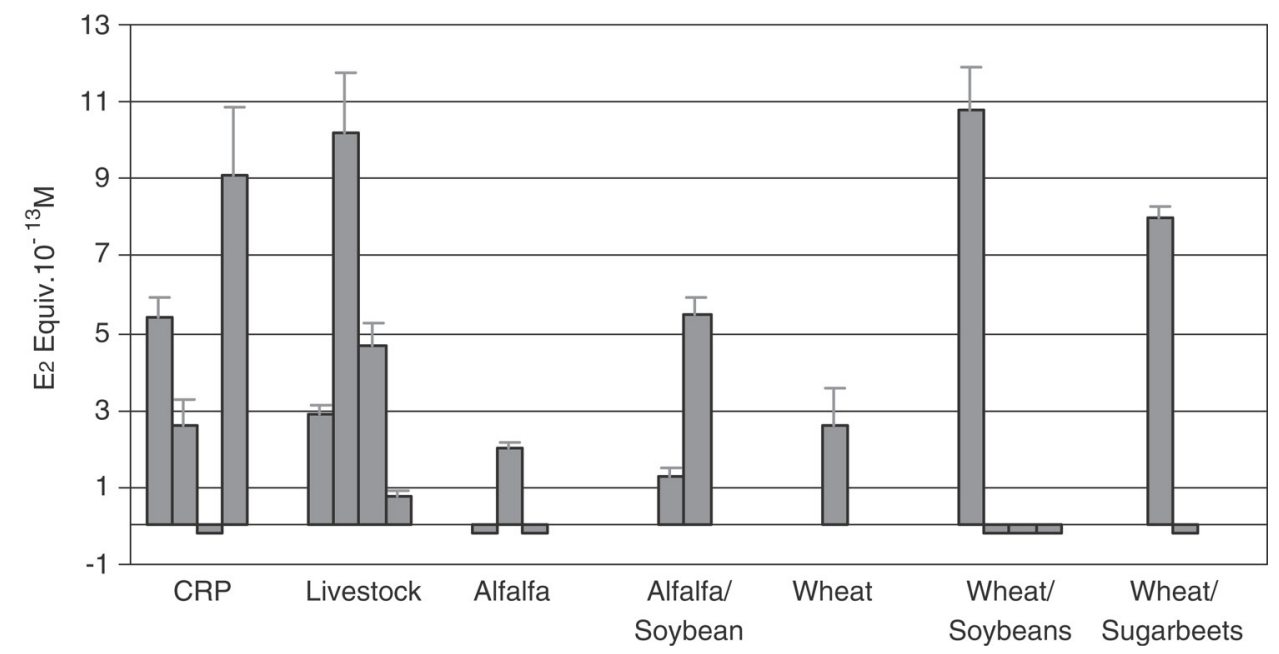

Fig. 3. Estrogenic activity of wetland and pond sites from various land uses. Water samples from sites below the limits of quantitation ( $<3 \times 10^{-14} M$ ) are represented graphically as $-0.2 \times 10^{-13} M 17 \beta$-estradiol equivalents $\left(E_{2} E q\right)$. Sites are grouped by land use indicated on the $x$ axis, with one bar per site (mean \pm SD, $n=5$ ). CRP, Conservation Reserve Program land. 
animal feeding operation. The highest concentration of $\mathrm{E}_{2} \mathrm{Eq}$ found in water from a retention pond at a cattle feedlot in Nebraska was similar to our highest sample concentration $\left(1.7 \times 10^{-12} M\right.$; Soto et al., 2004). These authors reported water from nonimpacted sites had $\mathrm{E}_{2}$ $\mathrm{Eq}$ at one-third to one-fourth of the retention pond samples, similar to those seen in this study. Just as found by Soto et al. (2004) preliminary data indicated toxicity in some water samples, even at environmental concentrations. There was no correlation between toxicity and land use, and toxicity was found in at least one site in all land uses.

Recently metamorphosed $R$. pipiens harvested from the sites in this study appeared healthy and unaffected by site waters (Shappell and Gackle, unpublished data). Surveys of these frogs found malformation to be approximately $3 \%$, which reflects normal, historical background values. While the numbers of recently metamorphosed frogs dissected per site were small (approximately 10), sex ratios appeared to be undisturbed with the exception of three sites, where frog growth was so stunted that gonads were not developed enough to determine sex. One possible explanation for the stunted growth of these frogs may have been high cation concentrations found at these sites which were all within $1.6 \mathrm{~km}$ (1 mile) of each other. In laboratory studies using frogs, $\mathrm{E}_{2}$ concentrations of $\geq 1 \times 10^{-7} M$ were required before abnormalities were observed (Bevan et al., 2003; Nishimura et al., 1997) and limb malformation occurred when larvae were exposed to concentrations of $>5 \times 10^{-6} M$ (Takahashi, 1958). Ohtani et al. (2000) found exposure of Rana rugosa tadpoles to $1 \times 10^{-8} M \mathrm{E}_{2}$ or $1 \times 10^{-5} M$ dibutyl phthalate caused development of ovarian tissue in genetic males. Based on this literature, the low $\mathrm{E}_{2} \mathrm{Eq}$ concentrations found in the wetlands and ponds in this study would not be expected to result in malformations and sexual abnormalities.

\section{River Sites}

Differences in estrogenic activity of Red River samples were apparent across seasons $(P<0.0001$; Fig. 4$)$. There may have been a trend for differences across sampling sites, but due to the limited number of sites assayed statistical analysis was inappropriate. Estrogenic activity was below the limit of quantitation at the
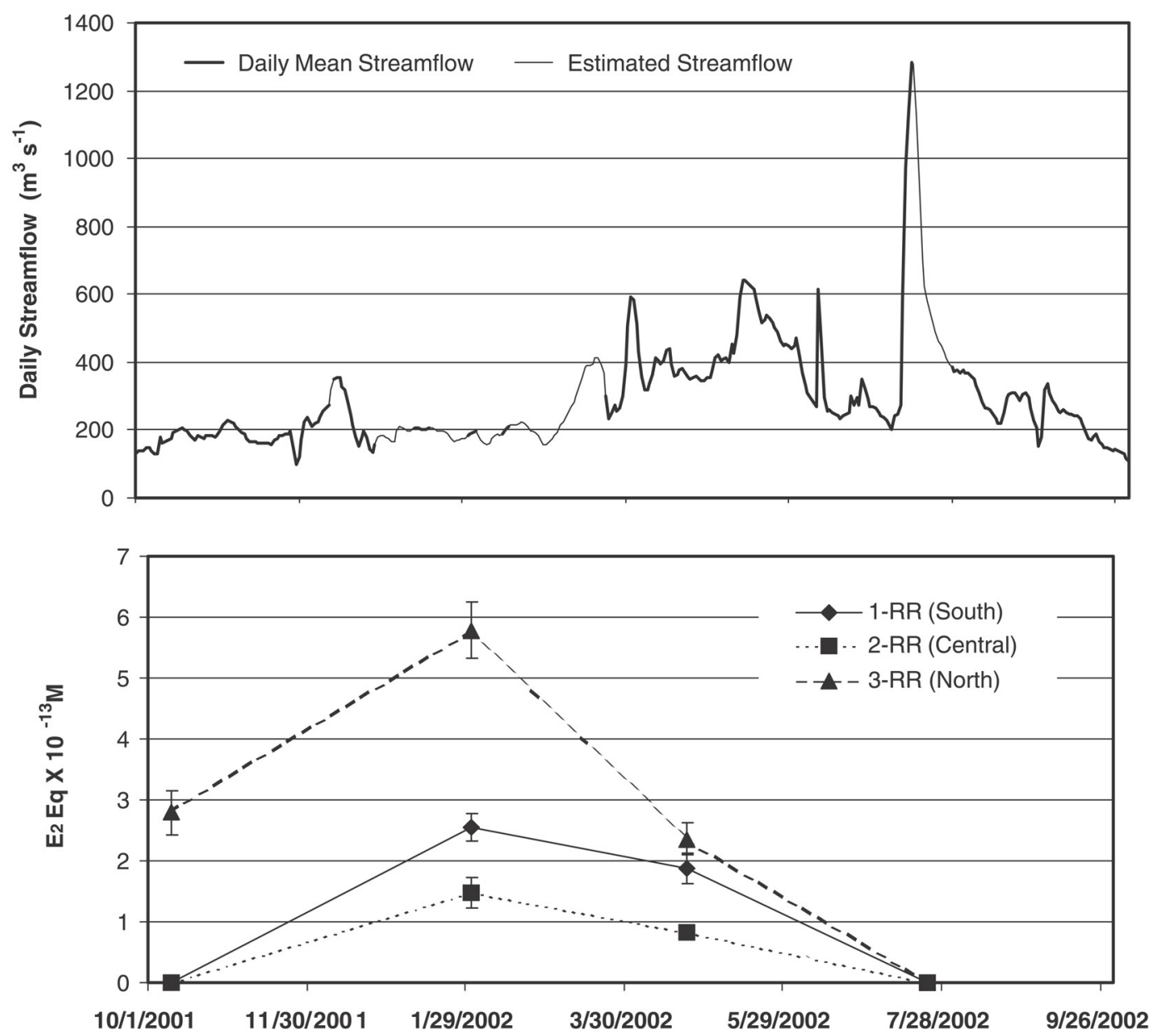

Fig. 4. Estrogenic activity of Red River (RR) water over four seasons and Red River flow. Top: Red River flow at Fargo, ND (proximal to 1-RR), 1 Oct. 2001 through 30 Sept. 2002. Data courtesy of USGS (2002). Estimated streamflow measurements in winter months reflect adjustments made for ice cover, while in July they reflect adjustments made for backwater flow due to a flat river slope in times of high flow. Bottom: 17ק-estradiol equivalents $\left(E_{2} E q\right)( \pm S D, n=6)$ from $E$-screen analysis of samples collected 10 Oct. 2001, 31 Jan. 2002, 23 Apr. 2002 , and 23 July 2002, from sites located on Fig. $1 B$. 
two sites (1-RR and 2-RR) upstream from release of municipal wastewater effluents for the twin cities of Fargo, ND, and Moorhead, MN, for two out of the four seasons sampled. Evaluation of river water withdrawal data and wastewater effluent release data (data obtained from municipal facilities, data not shown) revealed water withdrawal was approximately equal to effluent released. Variabilities (coefficients of variation) in monthly averages for withdrawal and release were 16 and $9 \%$ for Fargo and 8 and $10 \%$ for Moorhead, respectively. The lower variability in Moorhead withdrawal values most likely reflects use of well water during times of higher public consumption, in turn minimizing the impact on the river in times of high demand. These data imply that over the year volume changes due to the removal of river water for municipal usage and release of wastewater effluent were relatively constant, and therefore changes in concentration of estrogenic activity of the river were due to other factors.

While the site downstream of the major municipalities (3-RR) was predictably and consistently the highest in estrogenic activity, it had no $\mathrm{E}_{2}$ Eq activity detected in the summer sample. The highest activity was seen in winter samples, at approximately $2 \times 10^{-13} M \mathrm{E}_{2} \mathrm{Eq}$ for 1-RR and 2-RR, and approximately $6 \times 10^{-13} M$ for the downstream site (3-RR). The decrease in concentration of estrogenic activity of 3-RR from winter to spring (5.8 to $2.4 \times 10^{-13} M \mathrm{E}_{2} \mathrm{Eq}$ ) is most likely accounted for by several factors, including change in river volume due to spring snow melts, which increased flow approximately twofold (stream flow as measured by USGS [Fig. 4] approximately $190 \mathrm{~m}^{3} \mathrm{~s}^{-1}$ in January $2002 \mathrm{vs.} 400 \mathrm{~m}^{3} \mathrm{~s}^{-1}$ in April 2002). Further, wastewater influent-effluent in this region in spring can be diluted by the input of residential sump pumps which empty into municipal sewer lines and storm water systems that empty into the wastewater treatment plant. This increases flow through the plant, and dilutes total waste solids handled. In addition, monthly total suspended solids (TSS; Fig. 5) released by municipal wastewater treatment plants (MWWTPs) upstream of 3-RR were reduced by approximately $22 \%$ from January to April 2002 (30131 vs. 23532 kg; Fig. 5). At the time of summer sampling in 2002, flooding resulted in a river flow rate of 1280 to $686 \mathrm{~m}^{3} \mathrm{~s}^{-1}$. The lower estrogenic activity of the summer 3-RR site sample was probably also a reflection of reduced TSS from MWWTPs directly upstream of 3-RR (July 2002 TSS was $65 \%$ of January 2002). There were no MWWTP releases directly upstream from 1-RR for either January or July 2002 (Fig. 5) so decreased estrogenic activity of 1-RR and 2-RR at summer sampling was most likely a reflection of dilution with increased river flow.

The increase in activity seen for all sites from fall to winter does not correlate to change in river flow, as flow was similar for both times (approximately $165 \mathrm{~m}^{3} \mathrm{~s}^{-1}$ ). Precipitation events (e.g., rainfall, presumably devoid of estrogenic activity) decrease in the winter, and their contribution to river volume decreases. The relative percent of river volume from municipal wastewater effluent concomitantly increases, which would cause the concentration of estrogenic activity to increase. The similarity of estrogenic activity of 1-RR and 2-RR across all seasons would be expected as there are no known agricultural or MWWTP release sites between these sites. The decrease in activity seen from 1-RR to 2-RR may be a reflection of the distance from the upstream MWWTPs $(119 \mathrm{~km}$ to $1-\mathrm{RR}$ and a total of $156 \mathrm{~km}$ to $2-\mathrm{RR}$ in river kilometers). Two small municipalities upstream from 1-RR have MWWTPs that release into the Red River, which provide another potential source of estrogenic activity. Increased estrogenic activity downstream from MWWTPs was present. The estrogenic activity of a river could be expected to increase downstream of each municipality, with a net positive cumulative effect.

Placed in context, the highest Red River sample was approximately one order of magnitude lower than the mean concentration of estradiol reported by Kolpin et al. (2002) as cited above. As far as biological activity, the concentration is approximately $1 / 100$ of the ethinylestradiol used to induce vitellogenin synthesis in male fish in vivo (Palace et al., 2002). Reports by Rose et al. (2002) cite concentrations of $21 \mathrm{ng} \mathrm{L}^{-1} \mathrm{E}_{2}\left(7.7 \times 10^{-11}\right.$ $M)$ and $3 \mathrm{ng} \mathrm{L}^{-1}$ ethinylestradiol $\left(1 \times 10^{-11} M\right)$ for induction of vitellogenin in male zebra fish (Danio rerio).

An unexpected finding was apparent toxicity or antiestrogenicity in some Red River extracts (Fig. 5). When fall 2001 samples were tested at fourfold the environmental concentration in the presence of $\mathrm{E}_{2}\left(8 \times 10^{-12}\right.$ $M$ ), cell proliferation ranged from 42 to $70 \%$ of $\mathrm{E}_{2}$ alone. Using the same conditions, summer 2002 samples produced only 18 to $28 \%$ of $E_{2}$ alone. Although fecal coliform data reported for the three river sites indicated incidences of sporadic contamination, the largest being 2800 colony forming units (CFUs) per $100 \mathrm{~mL}$, these incidences did not correlate to the periods of apparent toxicity (data obtained from Energy \& Environmental Research Center, and municipalities). In addition, the site with the consistently highest colony forming units (3-RR) was in fact the site with the lowest apparent toxicity. A clear relationship does not exist between monthly release of TSS (Fig. 5) and toxicity. Under the conditions of the E-screen assay, toxicity of extracts was tested on MDA-MB-231 and WI-38 cells. Preliminary data reflect similar, but less severe toxicity of samples on MDA-MB-231 cells (derived from a human mammary carcinoma, but estradiol insensitive), but no toxicity on WI-38 cells (human lung fibroblasts). These results indicate no generalized cellular toxicity of extracts (that is universal across cell types). The usefulness of an organismal environmental toxicity assay is suggested by these results. In fact a recent publication by Schiliro et al. (2004) evaluated sewage treatment plant samples by E-screen assay, the Microtox assay, and Daphnia magna assay. They reported toxicity by assay standards for only influent samples, and toxicity was not present in all effluent assays. These results indicate that while such assays may assess environmental toxicity at the organismal level, they will not necessarily reflect toxicity found in in-vitro cell screens. Therefore these screens need to be considered in light of potential cellular toxicity or anti-estrogenic activity of complex environmental extracts. 

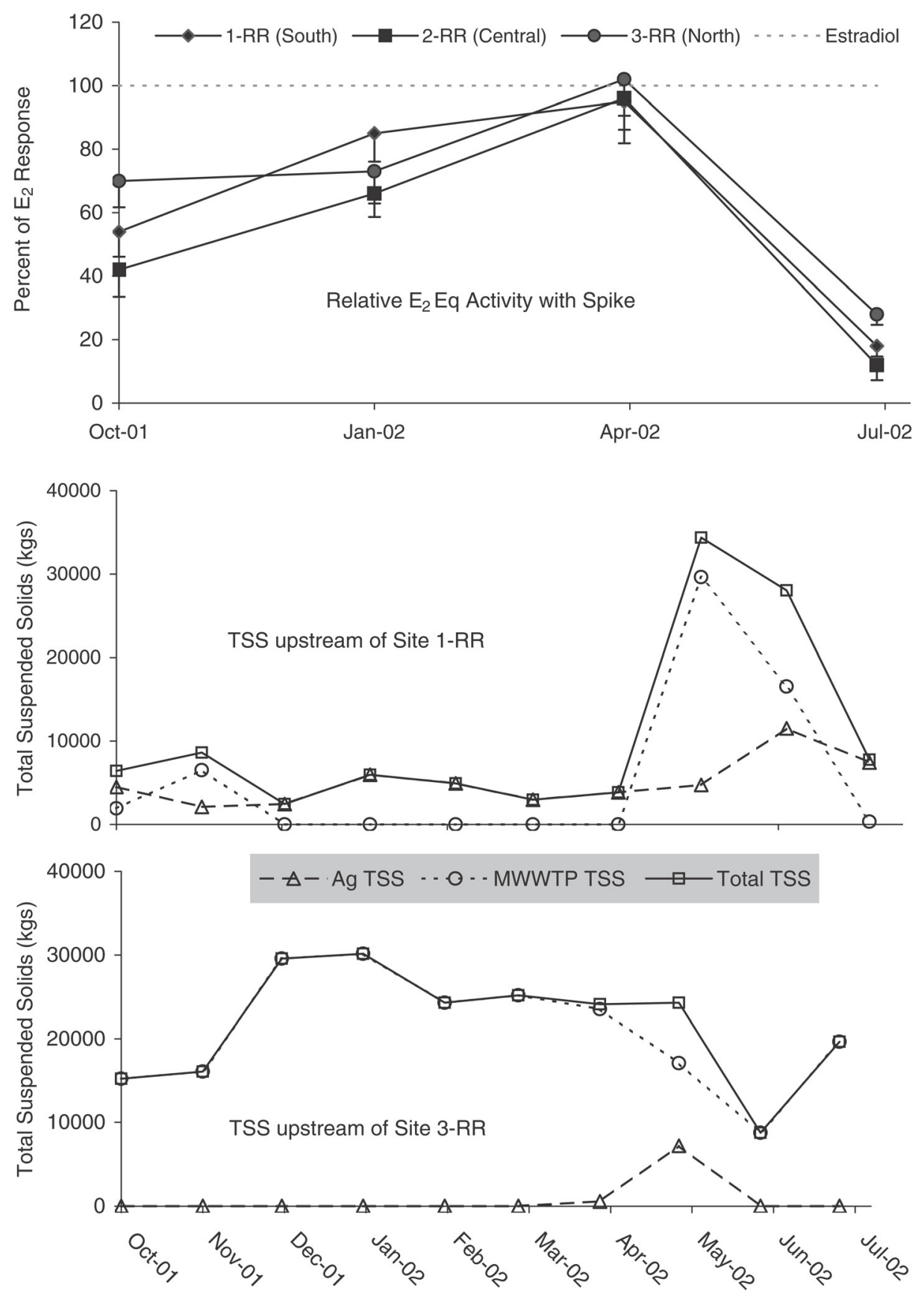

Fig. 5. Relative anti-estrogenic or toxic activity of Red River water samples versus total suspended solids of the Red River. Samples extracted for evaluation of estrogenic activity (Fig. 4) were tested at fourfold environmental concentrations in the presence of $8 \times 10^{-12} M 17 \beta$-estradiol $\left(E_{2}\right)$. Values represent percent of cell response in the presence of $E_{2}$ alone $(100 \%)$ minus $17 \beta$-estradiol equivalents $\left(E_{2} E q\right)$ in the sample alone; error bars reflect SD $(n=6)$. The bottom two graphs show total suspended solids (TSS, kg) released into the Red River (RR) by month upstream of sampling sites 1-RR and 3-RR from municipal wastewater treatment plants (MWWTP) and agricultural wastewater (Ag). Data were obtained from municipalities and compiled.

\section{Municipal Wastewater Effluent and Lagoons}

The estrogenic activity of the lagoon at the time of filling (9 May 2001) was very similar to the effluent sample taken 21 May 2001 (Table 1). In comparison to the estrogenic activity of the lagoon that was currently being filled, activity was approximately $90 \%$ lower in the lagoon that had not had new effluent added for over a month, and approximately $97 \%$ lower in the lagoon that had been inactive for more than 6 mo. These data might represent a picture of rapid "degradation" or possible sedimentation of activity with particulates. Without knowing the history of the effluent being added to each lagoon, a conclusion about degradation was unwarranted. To determine if estrogenic activity was decreasing in lagoons, the following spring lagoons were treated as described in the Materials and Methods. Effluent was monitored during the 35-d fill period and estrogenic activity of the effluent ranged from 7.6 to $3.6 \times 10^{-12} M \mathrm{E}_{2}$ 
Table 1. Initial testing of Fargo, ND, municipal wastewater effluents $\dagger$ and lagoonsł.

\begin{tabular}{lc}
\hline Sample, date collected & $\mathbf{E}_{\mathbf{2}}$ Eq \pm SD \\
\hline & $\times 10^{-12} M$ \\
Wastewater effluent, 21 May 2001 & $\mathbf{8 . 8} \pm \mathbf{0 . 7 7}$ \\
Lagoon samples during filling, 9 May 2001 & $\mathbf{7 . 1} \pm \mathbf{0 . 4 6}$ \\
Lagoon samples approximately 1 mo post-fill, 9 May 2001 & $\mathbf{0 . 6} \pm \mathbf{0 . 0 5}$ \\
Lagoon samples $\geq 6$ mo post-fill, 9 May 2001 & $\mathbf{0 . 2} \pm \mathbf{0 . 0 2}$ \\
Wastewater effluent & $\mathbf{7 . 7} \pm \mathbf{0 . 8 1}$ \\
23 Jan. 2002 & $\mathbf{7 . 6} \pm \mathbf{0 . 4 3}$ \\
20 May 2002 & $\mathbf{6 . 7} \pm \mathbf{0 . 8 7}$ \\
3 June 2002 & $3.6 \pm 0.62$ \\
17 June 2002 & $\mathbf{4 . 1} \pm \mathbf{0 . 4 4}$ \\
24 June 2002
\end{tabular}

$\dagger$ Wastewater effluent was collected post-treatment, pre-release to lagoons. $¥$ Lagoons were sampled on the east side only.

$\S 17 \beta$-Estradiol equivalents \pm standard deviation $(n=5)$.

Eq (Table 1). The last and lowest value was seen after a flooding event, which is reflected in elevated Red River flows in mid-June (Fig. 4). Dilution and an increase in liters of effluent released, as a result of significant rain events, are easy to track, as residence time of treated sewage within this MWWTP is approximately $1 \mathrm{~d}$. In contrast, in the absence of significant rain events, estrogenic activity in effluent sampled in May 2001 was very similar to that found in May $2002\left(8.8\right.$ vs. $7.6 \times 10^{-12} M$ $\left.\mathrm{E}_{2} \mathrm{Eq}\right)$ and also similar to that obtained in January 2002 $\left(7.7 \times 10^{-12} M \mathrm{E}_{2} \mathrm{Eq}\right)$ indicating a consistency of "product" released. While for experimental purposes, the effluent was pumped to lagoons, it could have been released directly to the Red River as determined by municipal wastewater release standards.

The concentration of the effluent was approximately 10-fold the highest concentration found in our sampling of the Red River (winter 2001, 3-RR), and was very similar to those reported for effluent from MWWTP in southern Germany, which ranged from 9 to $90 \times 10^{-12} M$ $\mathrm{E}_{2} \mathrm{Eq}$ as measured by E-screen (Korner et al., 1999). Effluent was sampled five times over a year from a pilot scale sludge treatment plant and assayed by LC-MS/MS for estrone, estradiol, and estriol (Onda et al., 2003). The sum $E_{2} E q$ values for the average of these three compounds was $6.4 \times 10^{-12} \mathrm{M}$. Applying the same technique described above, MWWTP effluents quantified by LCMS/MS and reported by Nakamura et al. (2003) yielded $8.1 \times 10^{-12} M \mathrm{E}_{2} \mathrm{Eq}$. A similar comparison of data from MWWTP effluents in France yielded higher estimates $\left(71 \times 10^{-12} M \mathrm{E}_{2} \mathrm{Eq}\right)$, but this may be a reflection that $\mathrm{E}_{2}$ and ethinylestradiol were reported only as less than approximately $35 \times 10^{-12} M$ each (Ingrand et al., 2003). In general, the estrogenic activity of MWWTP effluents analyzed here was remarkably similar to others reported worldwide.

Estrogenic activity of undisturbed lagoons (control) and recently filled lagoons (treated) is presented in Fig. 6. Lagoons 4 and 1 were analyzed side by side, and before other lagoons. Apparent exponential decay was modeled for Lagoon 1: $y=7.715+16.316 \mathrm{e}^{(-0.152 x)}, R^{2}=$ 0.96 . The half-life of estrogenic activity was calculated to be approximately $8 \mathrm{~d}$. While these results looked promising, analyses of samples from the remaining lagoons did not follow the same trend. Estrogenic activity of the control lagoons (4 and 6) was similar for the first $16 \mathrm{~d}$ of testing, but later activity in Lagoon 6 increased dramatically. The dissimilarity in the two lagoons was also evident in the type and quantity of algae found throughout the experimental period, as well as the color of samples post-extraction. When considering increased estrogenic activity in the control lagoons, at least three factors should be considered. First, microbes or algae can degraded alkylethoxylates and/or deconjugated estrogen metabolites resulting in more active forms of both constituents (Staples et al., 2001; D'Ascenzo et al., 2003). As lagoon temperatures rise during the summer, it would be reasonable to assume increased metabolism-degradation by an increased microbial and algal biomass. Second, increased activity may reflect bioaccumulation by algae (in Lagoon 6). Work by Takahashi et al. (2003) reports bioaccumulation of nonylphenols by periphyton ranging from 160- to 650fold and, for $\mathrm{E}_{2}$, 64- to 1200-fold. Third, increased activity might have been the result of wildlife. As cited earlier, avians are known to have high levels of circulating estradiol concentrations, and fecal material from waterfowl at the lagoons was present. Many species of waterfowl were in residence, including Canadian geese which were nesting along the lagoons. Analysis of water samples for chemical composition by LC-MS/MS would allow for determination of the source of estrogenic activity (alkylethoxylates or nonophenols-breakdown products of plasticizers and detergents, or metabolites of natural $\mathrm{E}_{2}$ or ethinylestradiol).

A high degree of variability in estrogenic activity was also found in the two other "treated" lagoons (2 and 3). On Day 16 estrogenic activity in Lagoon 2 increased to concentrations approximately equal to Day 0 . A large storm event occurred on Day 15 and high winds were present on Day 16. Due to the configuration of the lagoons, winds had access to Lagoon 2, and in fact, records show whitecaps were present in Lagoon 2 that day. The resultant turbulence allowed for agitation and mixing of the lagoon contents, reflected in the granular, brownish appearance of the sample from Lagoon 2. If higher estrogenic activity was present in association with larger particles, as Bowman et al. (2002) reported for estrone and $E_{2}$, then these results would be expected, and suggest that the decrease in activity seen in surface sampling of Lagoons 1 and 2 over the previous days was more a reflection of particulate deposition-sedimentation than of true decay of activity.

A positional effect may have also played a factor in another "treated" lagoon, Lagoon 3, which is the northern-most lagoon. Lagoons 1 and 3 were filled with effluent from the lateral release from Lagoon 2 (situated between Lagoons 1 and 3). As there was no evidence of filling failures or discrepancies (level of all three lagoons was similar), prevailing winds out of the north may have favored flow of particulates into the southern-most lagoon (1) and disfavored Lagoon 3. Drop in estrogenic activity seen in Lagoon 3 on Day 28 was associated with toxicity, also found in Lagoon 2 on Days 28, 42, and 84. Biological-organismal significance of toxicity in Lagoon 3 on Day 28 was indicated, as a die-off of snails was also recorded at that lagoon that day. While there is no 


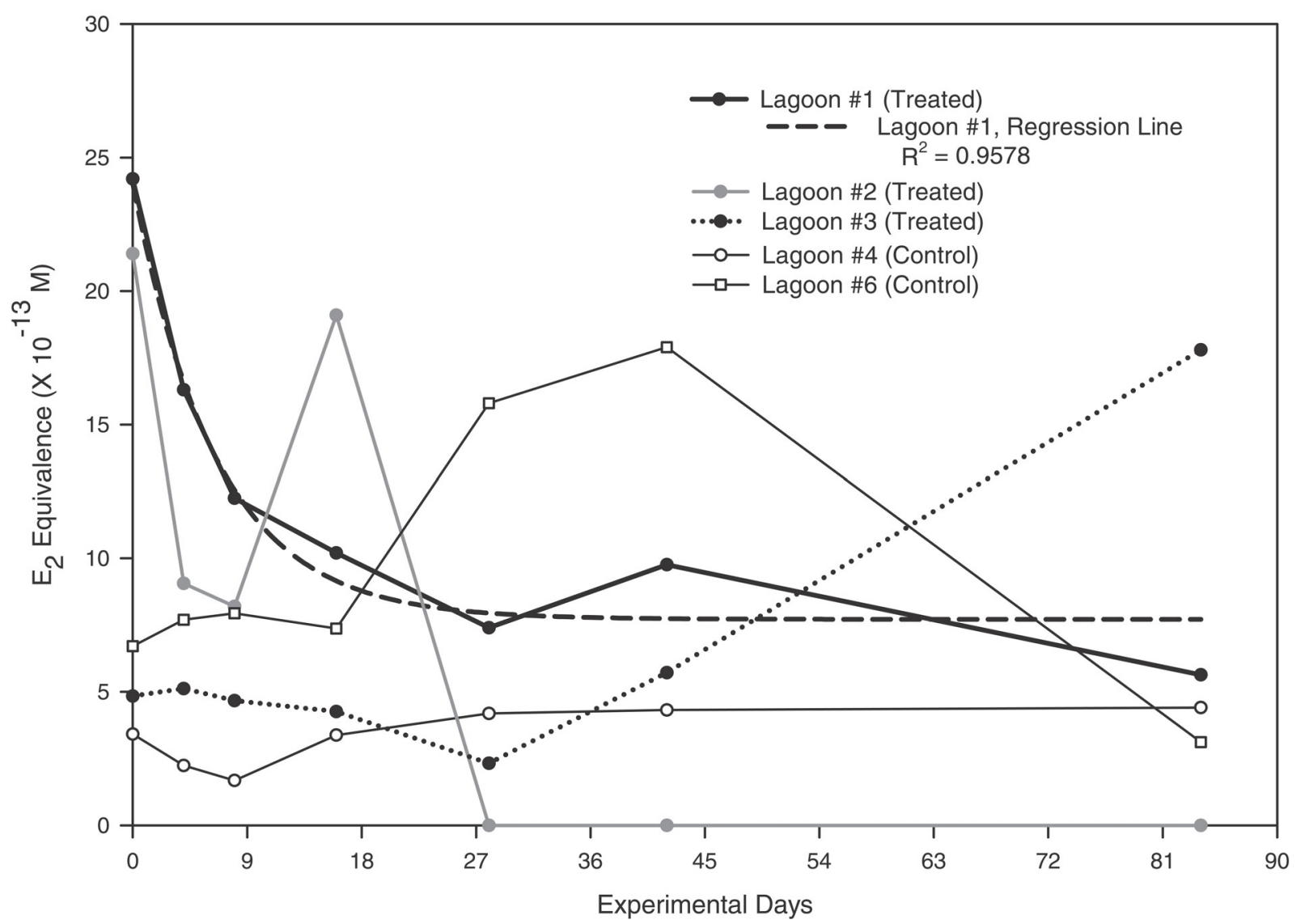

Fig. 6. Estrogenic activity in wastewater effluent in holding lagoons. Day 0 (24 June 2002) was the completion date of lagoon filling (active or treated). Control lagoons had no wastewater effluent added to them for the 8 mo before Day 0 . Values represent mean 17 $\beta$-estradiol equivalents $\left(E_{2} E q\right) \pm S D, n=5$. The regression curve for the decay model for Lagoon 1 represents exponential decay: $y=7.715+16.316 \mathrm{e}^{(-0.152 r)}$.

apparent explanation for the unique increase in activity seen in samples from Lagoon 3 on Days 42 and 84, repeated extractions of samples yielded values that were $\pm 14 \%$ of original values with a coefficient of variation of 5 .

After $295 \mathrm{~d}$, all lagoons had $2 \times 10^{-13} M \mathrm{E}_{2}$ Eq or less, and Lagoons 2 and 6 were below the limits of quantitation. All estrogenic activity reported for MWWTP effluent and lagoons was estrogen-receptor dependent, as proliferation was inhibited by co-incubation with estrogen-receptor antagonist. Taken in total, the results from the lagoon analyses indicate a need to repeat this type of experiment using mini-lagoons, where it is possible to prevent wildlife access, establish equivalent algal and microbial composition among lagoons, and mix contents of lagoons before sampling to ensure a homogenous sample and removal of the confounding effect of particulate settling. While the results were disparate, they documented the "natural" variability that could be expected in surface sampling of lagoons. Presently, modifications at some MWWTPs have made lagoons unnecessary in the treatment of waste and they are typically being used only as a means of controlling effluent release. Use of lagoons entails considerable expense (construction and maintenance costs as well as power required to pump effluent to the lagoons). It should be determined if these lagoons are capable of significantly reducing environmental impact of wastewater contaminants, before their usage becomes obsolete.

\section{CONCLUSIONS}

By use of the highly sensitive E-screen, estrogenic activity was detected in $65 \%$ of regional waters tested (wetlands, ponds, and river). In all cases the concentration of activity found in water from these sites was below the concentration required to affect fish. Estrogenic activity of municipal wastewater effluents was approximately 10-fold higher than other water samples, but comparable to those reported by others worldwide. These data provide a perspective of "indigenous" and anthropogenic estrogenic activity in waters for evaluating E-screen results from sites with presumed estrogenic contamination.

\section{ACKNOWLEDGMENTS}

The author would like to acknowledge the dedicated efforts of Mr. Lloyd Billey in sample collection, extraction, and E-screen analyses. Natalie Gackle surveyed and necropsied frogs and collected associated water samples. Colleen Pfaff provided ELISA data for the estradiol and testosterone analyses of serum. Wastewater treatment plant operators and water treatment operators and management, Energy \& Environmental Research Center, and the USGS were extremely 
helpful in obtaining samples and river total suspended solids, fecal coliform, usage, and flow data. Dr. Ana Soto and Dr. Carlos Sonnenschein graciously provided cells and access to their laboratories to learn E-screen methodology.

\section{REFERENCES}

Allen, Y., A.P. Scott, P. Matthiessen, S. Haworth, J.E. Thain, and S. Feist. 1999. Survey of estrogenic activity in United Kingdom estuarine and coastal waters and its effects on gonadal development of the flounder Platichthys flesus. Environ. Toxicol. Chem. 18: 1791-1800.

American Public Health Association. 1998. Standard methods for the examination of water and wastewater. 20th ed. Am. Public Health Assoc., Washington, DC.

Baird, D.T., and A. Guevara. 1969. Concentration of unconjugated estrone and estradiol in peripheral plasma in nonpregnant women throughout the menstrual cycle, castrate and postmenopausal women and in men. J. Clin. Endocrinol. Metab. 29:149-156.

Bevan, C.L., D.M. Porter, A. Prasad, M.J. Howard, and L.P. Henderson. 2003. Environmental estrogens alter early development in Xenopus laevis. Environ. Health Perspect. 111:488-496.

Bowman, J.C., J.L. Zhou, and J.W. Readman. 2002. Sediment-water interactions of natural oestrogens under estuarine conditions. Mar. Chem. 77:263-276.

Cockrem, J.F., and J.R. Rounce. 1994. Faecal measurements of oestradiol and testosterone allow the non-invasive estimation of plasma steroid concentrations in the domestic fowl. Br. Poult. Sci. 35:433-443.

D'Ascenzo, G., A. Di Corcia, A. Gentili, R. Mancini, R. Mastropasqua, M. Nazzari, and R. Samperi. 2003. Fate of natural estrogen conjugates in municipal sewage transport and treatment facilities. Sci. Total Environ. 302:199-209.

Guillette, L.J., Jr., T.S. Gross, G.R. Masson, J.M. Matter, F.H. Percival, and A.R. Wood. 1994. Developmental abnormalities of the gonad and abnormal sex hormone concentrations in juvenile alligators from contaminated and control lakes in florida. Environ. Health Perspect. 102:680-688.

Harries, J.E., D.A. Sheahan, S. Jobling, P. Matthiessen, P. Neall, E.J. Routledge, R. Rycroft, J.P. Sumpter, and T. Tylor. 1996. A survey of estrogenic activity in United Kingdom inland waters. Environ. Toxicol. Chem. 15:1993-2002.

Ingrand, V., G. Herry, J. Beausse, and M.-R. de Roubin. 2003. Analysis of steroid hormones in effluents of wastewater treatment plants by liquid chromatography-tandem mass spectrometry. J. Chromatogr. A 1020:88-104.

Kolpin, D.W., E.T. Furlong, M.T. Meyer, M. Thurman, S.D. Zaugg, L.B. Barber, and H.T. Buxton. 2002. Pharmaceuticals, hormones, and other organic wastewater contaminants in U.S. streams, 1999-2000: A national reconnaissance. Environ. Sci. Technol. 36: $1202-1211$.

Korner, W., V. Hanf, W. Schuller, H. Bartsch, M. Zwirner, and H. Hagenmaier. 1998. Validation and application of a rapid in vitro assay for assessing the estrogenic potency of halogenated phenolic chemicals. Chemosphere 37:2395-2407.

Korner, W., V. Hanf, W. Schuller, C. Kenpter, J. Metzger, and H. Hagenmaier. 1999. Development of a sensitive e-screen assay for quantitative analysis of estrogenic activity in municipal sewage plant effluents. Sci. Total Environ. 225:33-48.

Munro, C.J., G.H. Stabenfeldt, J.R. Cragun, L.A. Addiego, J.W. Overstreet, and B.L. Lasley. 1991. Relationship of serum estradiol and progesterone concentrations to the excretion profiles of their major urinary metabolites as measured by enzyme immunoassay and radioimmunoassay. Clin. Chem. 37:838-844.

Nakamura, Y., K. Onda, C. Takatoh, and A. Miya. 2003. Development of a method for the quantitative analysis of estrogens in sewage water by LC/MS/MS. Bunseki Kagaku 52:107-114.

Nishimura, N., Y. Fukazawa, H. Uchiyama, and T. Iguchi. 1997. Effects of estrogenic hormones on early development of Xenopus laevis. J. Exp. Zool. 278:221-233.

Ohtani, H., I. Miura, and Y. Ichikawa. 2000. Effects of dibutyl phthalate as an environmental endocrine disruptor on gonadal sex differentiation of genetic males of the frog Rana rugosa. Environ. Health Perspect. 108:1189-1193.

Onda, K., Y. Nakamura, C. Takatoh, A. Miya, and Y. Katsu. 2003. The behavior of estrogenic substances in the biological treatment process of sewage. Water Sci. Technol. 47:109-116.

Palace, V.P., R.E. Evans, K. Wautier, C. Baron, L. Vandenbyllardt, W. Vandersteen, and K. Kidd. 2002. Induction of vitellogenin and histological effects in wild fathead minnows from a lake experimentally treated with the synthetic estrogen, ethynylestradiol. Water Qual. Res. J. Can. 37:637-650.

Peterson, E.W., R.K. Davis, and H.A. Orndorff. 2000. 17 $\beta$-Estradiol as an indicator of animal waste contamination in mantled karst aquifers. J. Environ. Qual. 29:826-834.

Rasmussen, T.H., and J.B. Nielsen. 2002. Critical parameters in the MCF-7 cell proliferation bioassay (E-Screen). Biomarkers 7:322-336.

Rose, J., H. Holbech, C. Lindholst, U. Norum, A. Povlesen, B. Korsgaard, and P. Bjerregaard. 2002. Vitellogenin induction by $17 \beta$-estradiol and $17 \alpha$-ethinylestradiol in male zebrafish (Danio rerio). Comp. Biochem. Physiol. C 131:531-539.

Safe, S.H., L. Pallaroni, K. Yoon, K. Gaido, S. Ross, and D. McDonnell. 2002. Problems for risk assessment of endocrine-active estrogenic compounds. Environ. Health Perspect. 110:925-929.

SAS Institute. 1999. PROC GENMOD and PROC MIXED. SAS user's guide: Statistics. Version 8 ed. SAS Inst., Cary, NC.

Schiliro, T., C. Pignata, E. Fea, and G. Gilli. 2004. Toxicity and estrogenic activity of a wastewater treatment plant in northern Italy. Arch. Environ. Contam. Toxicol. 47:456-462.

Skehan, P., R. Storeng, D. Scudiero, A. Monks, J. McMahon, D. Vistica, J.T. Warren, H. Bokesch, S. Kenney, and M.R. Boyd. 1990. New colorimetric cytotoxicity assay for anticancer-drug screening. J. Natl. Cancer Inst. 82:1107-1112.

Soto, A.M., J.M. Calabro, N.V. Prechtl, A.Y. Yau, E.F. Orlando, A. Daxenberger, A.S. Kolok, L.J. Guillette, B. Bizec, I.G. Lange, and C. Sonnenschein. 2004. Androgenic and estrogenic activity in water bodies receiving cattle feedlot effluent in eastern Nebraska, USA. Environ. Health Perspect. 112:346-352.

Soto, A.M., C. Sonnenschein, K.L. Chung, M.F. Fernandez, N. Olea, and F.O. Serrano. 1995. The E-screen assay as a tool to identify estrogens: An update on estrogenic environmental pollutants. Environ. Health Perspect. 103(Supplement 7):113-122.

Staples, C.A., C.G. Naylor, J.B. Williams, and W.E. Gledhill. 2001. Ultimate biodegradation of alkylphenol ethoxylate surfactants and their biodegradation intermediates. Environ. Toxicol. Chem. 20: 2450-2455.

Takahashi, A., T. Higashitani, Y. Yakou, M. Saitou, H. Tamamoto, and H. Tanaka. 2003. Evaluating bioaccumulation of suspected endocrine disruptors into periphytons and benthos in the Tama River. Water Sci. Technol. 47:71-76.

Takahashi, H. 1958. Time relation between the administration of estradiol and the occurrence of abnormalities in limbs and gonads of frog larvae. J. Fac. Sci. Hokkaido Univ. Ser. VI 14:101-110.

USGS. 2002. Red River of the north flow data for Fargo, ND. Available at http://nwis.waterdata.usgs.gov/nd/nwis/discharge?site no $=05054000 \&$ agency_cd=USGS\&begin_date $=2001-10-1 \&$ end date $=2002-10-1 \&$ format $=$ gif $\&$ set_logscale_y $=1 \&$ date_format $=$ YYYY-MM-DD\&rdb_compression=file\&submitted_form=brief list (verified 21 Sept. 2005). USGS, Reston, VA.

Vandenlangenberg, S.M., J.T. Canfield, and J.A. Magner. 2003. A regional survey of malformed frogs in Minnesota (USA) (Minnesota malformed frogs). Environ. Monit. Assess. 82:45-61.

Wakeling, A.E., M. Dukes, and J. Bowler. 1991. A potent specific pure antiestrogen with clinical potential. Cancer Res. 51:3867-3873.

Wiese, T.E., L.G. Kral, K.E. Dennis, W.B. Butler, and S.C. Brooks. 1992. Optimization of estrogen growth response in MCF-7 cells. In Vitro Cell. Dev. Biol. 28A:595-602. 